(C) 2021, The Authors. Published by Elsevier Inc. and Fass Inc. on behalf of the American Dairy Science Association ${ }^{\circledR}$. This is an open access article under the CC BY-NC-ND license (http://creativecommons.org/licenses/by-nc-nd/4.0/).

\title{
Invited review: Bovine leukemia virus-Transmission, control, and eradication
}

\author{
Alessa Kuczewski, ${ }^{1}$ Karin Orsel, ${ }^{2}$ Herman W. Barkema, ${ }^{2}$ Steve Mason, ${ }^{3}$ Ron Erskine,${ }^{4}$ \\ and Frank van der Meer ${ }^{1 *}$ \\ ${ }^{1}$ Department of Ecosystem and Public Health, University of Calgary, Calgary, AB T2N 4Z6, Canada \\ ${ }^{2}$ Department of Production Animal Health, University of Calgary, Calgary, AB T2N 4Z6, Canada \\ ${ }^{3}$ Agromedia International Inc., Calgary, AB T2L 0T6, Canada \\ ${ }^{4}$ Large Animal Clinical Sciences, College of Veterinary Medicine, Michigan State University, East Lansing 48824
}

\section{ABSTRACT}

Bovine leukemia virus (BLV) infection, endemic in North American dairy herds, has production-limiting effects. A literature review of available papers published since 1995 concerning BLV transmission and its control was conducted. Although confirmed transmission routes were reviewed (blood, natural breeding, in utero, colostrum, and milk), there is still a lack of detailed information on other specific risks for transmission (e.g., contact transmission and hoof-trimming knives). Eradication of BLV has been achieved by combined management, segregation, and culling approaches. In contrast, although sole implementation of best management practices aimed at prevention of BLV transmission has decreased within-herd BLV prevalence, it has not eradicated BLV from a herd. Therefore, control and eradication of BLV by best management practices only should be further investigated. Additionally, the role of proviral load in infected cattle was investigated. Cattle with a high proviral load seem to be more likely to infect others, whereas those with a very low proviral load seem to have low risks of transmitting BLV. Information on proviral load could be taken into account when controlling BLV in high-prevalence herds. In conclusion, there is a need for detailed, large-scale studies investigating roles of specific transmission routes, knowing proviral load of infected individuals.

Key words: bovine leukemia virus, transmission, control, eradication

\section{INTRODUCTION}

Bovine leukemia virus (BLV), a member of the family Retroviridae, is able to infect bovine B-lymphocytes (Goff, 2013). Natural infection is not limited to cattle

Received May 21, 2020.

Accepted November 21, 2020

*Corresponding author: Frank.vandermeer@ucalgary.ca
(Bos taurus, Bos indicus) but also occurs in, for example, water buffalo (Bubalus bubalis) and capybaras (Hydrochoerus hydrochaeris). Some species (e.g., sheep, Ovis aries) can be infected experimentally (EFSA AHAW Panel, 2015), but the disease process differs from cattle because they develop tumors earlier and more frequently following challenge. Many other species generate an immune response upon experimental challenge with this virus (deer, rabbits, rats, guinea pigs, cats, dogs, sheep, rhesus monkeys, chimpanzees, antelopes, pigs, goats, and buffalo; OIE, 2018). Following infection, BLV integrates its genetic material into the host's genome, creating a provirus, an identical DNA copy of the virus' RNA genome (Goff, 2013), enabling BLV to establish lifelong persistent infection. Infection with BLV in cattle impairs immune system function, reduces cow longevity, and decreases milk production; in addition, it may culminate in development of enzootic bovine leukosis (EBL; fatal lymphosarcoma; Schwartz and Levy, 1994; Bartlett et al., 2014; Frie and Coussens, 2015). These tumors reduce production and animal welfare and cause premature death. Therefore, eradication of BLV has been a priority in the European Union since 1964 (EFSA AHAW Panel, 2015). Many Western European countries have eradicated BLV from their cattle population (European Commission, 2015). Similarly, New Zealand eradicated BLV from its dairy and beef herds, whereas Australia still has a low prevalence in its beef herds (Voges, 2012; Queensland Government Department of Agriculture and Fisheries, 2016). However, BLV infection is still common in North American dairy herds, averaging $\sim 90 \%$ herd prevalence and $\sim 40 \%$ within-herd prevalence (Nekouei et al., 2015; LaDronka et al., 2018; Kuczewski et al., 2019) despite the existence of several voluntary BLV control programs (Brunner et al., 1997; Canadian Food Inspection Agency, 2003).

Eradication programs in the European Union and elsewhere applied test and cull approaches, whereby frequent testing of all susceptible cattle and cull- 
ing test-positive individuals reduced prevalence and eventually removed the virus from herds (Burki, 1982; Mammerickx, 1984). In contrast to the North American situation, within-herd and between-herd prevalence of BLV in the European herds was still low when eradication was initiated (e.g., $6.1 \%$ of tested herds infected, $2.4 \%$ of tested cattle infected; Burki, 1982; Nuotio et al., 2003). As the within-herd prevalence in North American herds varies significantly, various approaches to effective BLV control strategies are likely necessary. Whereas culling test-positive animals would be possible in low-prevalence herds, it is often not economically feasible or practical in high-prevalence herds. In those herds, alternative approaches to control BLV can be implemented, such as segregation of BLV test-positive cattle and implementation of best management practices (BMP) aiming to reduce or prevent within-herd BLV transmission (Johnson et al., 1985; Shettigara et al., 1989). Recommendations concerning these approaches are generally based on studies and data from 1960 to 1990 (Rodríguez et al., 2011). However, the North American dairy industry has changed considerably since then. For example, tiestalls have often been replaced by freestalls and herd size keeps increasing (Barkema et al., 2015). Additionally, new insights in the biology of BLV, especially its epidemiology, could enable the adjustment of BLV control and eradication strategies to the North American situation. It was, for example, hypothesized that proviral load could affect BLV transmission risks (Juliarena et al., 2007; Jimba et al., 2010). When culling all positive cattle is not a viable option, strategic culling of high-risk (high proviral load) cattle could reduce transmission risk and within-herd prevalence.

\section{BLV CONTROL SINCE 1997: AN UPDATE}

A critical review of the literature published since 1997 was conducted to provide an overview of available knowledge on BLV transmission and control, identify gaps in knowledge, and assess the applicability of both historic and recent research to the current situation in the dairy industry. The last thorough review on BLV transmission was published in 1997 (Hopkins and DiGiacomo, 1997). Therefore, only literature regarding transmission studies from 1995 onward is included here (Table 1; Figure 1). A short summary of the historic findings of the previous review of Hopkins and DiGiacomo (1997) and a comparison with the literature as of 1995 reviewed herein is presented (Table 2). Topics included in this review are as follows: (1) BLV transmission in cattle (thus, the literature concerning transmission among other species such as sheep or goats as well as in vitro studies was excluded); (2) BLV control, including studies using voluntary control on individual or multiple farms (for information about mandatory national control programs, we refer to an extensive review by the European Food Safety Authority; EFSA AHAW Panel, 2015); and (3) BLV proviral load, regarding the potential of selecting cattle for culling based on proviral loads.

Additionally, in recent years, risk-assessment models were developed to identify on-farm causes of BLV transmission (Table 3); the risk factors identified are described in the following paragraphs. Generally, likely routes of BLV transmission are animal-to-animal contact, blood contact during natural breeding, vertical (e.g., in utero) transmission, peripartal transmission, and transmission through milk, colostrum, or both (Rodríguez et al., 2011; Lairmore, 2014). Additionally, some herd characteristics and management strategies with potential roles in BLV transmission were identified. Sources were categorized and a comprehensive summary of the role of proviral load in transmission and control of BLV is included in the final paragraph of the Results section.

\section{Horizontal Transmission}

Herd Characteristics and Management Strategies. Many risk analysis models identified herd characteristics that could alter the risk of BLV infection; these models were based on cross-sectional studies. Having a closed herd could decrease the risk of introduction of BLV into a herd and therefore decrease risk of BLV transmission and new infections (Nekouei et al., 2015). Conversely, previous detection of clinical EBL in a herd (Kobayashi et al., 2014; Nekouei et al., 2015) or increasing within-herd BLV infection rates (Şevik et al., 2015) were associated with increasing BLV prevalence on both dairy and beef farms. Introducing untested replacements (Casal et al., 1990; Kobayashi et al., 2014; Nekouei et al., 2015; Şevik et al., 2015; Sun et al., 2015), use of an independent heifer-rearing operation to manage replacements (Kobayashi et al., 2014), and larger herds (Şevik et al., 2015; Sun et al., 2015) all increased risks of BLV infection for dairy and beef herds.

Cattle breed is a potential risk for BLV infection. In a Turkish study, Holstein cattle had a higher risk of being BLV infected compared with Brown Swiss cattle (Şevik et al., 2015). Furthermore, although cattle origin was not mentioned, it could have contributed, as importation of Holsteins from North America has increased occurrence of BLV in other countries (Kavanagh, 1981; Suh et al., 2005). In the same study, increasing age within a herd was associated with an increased within- 

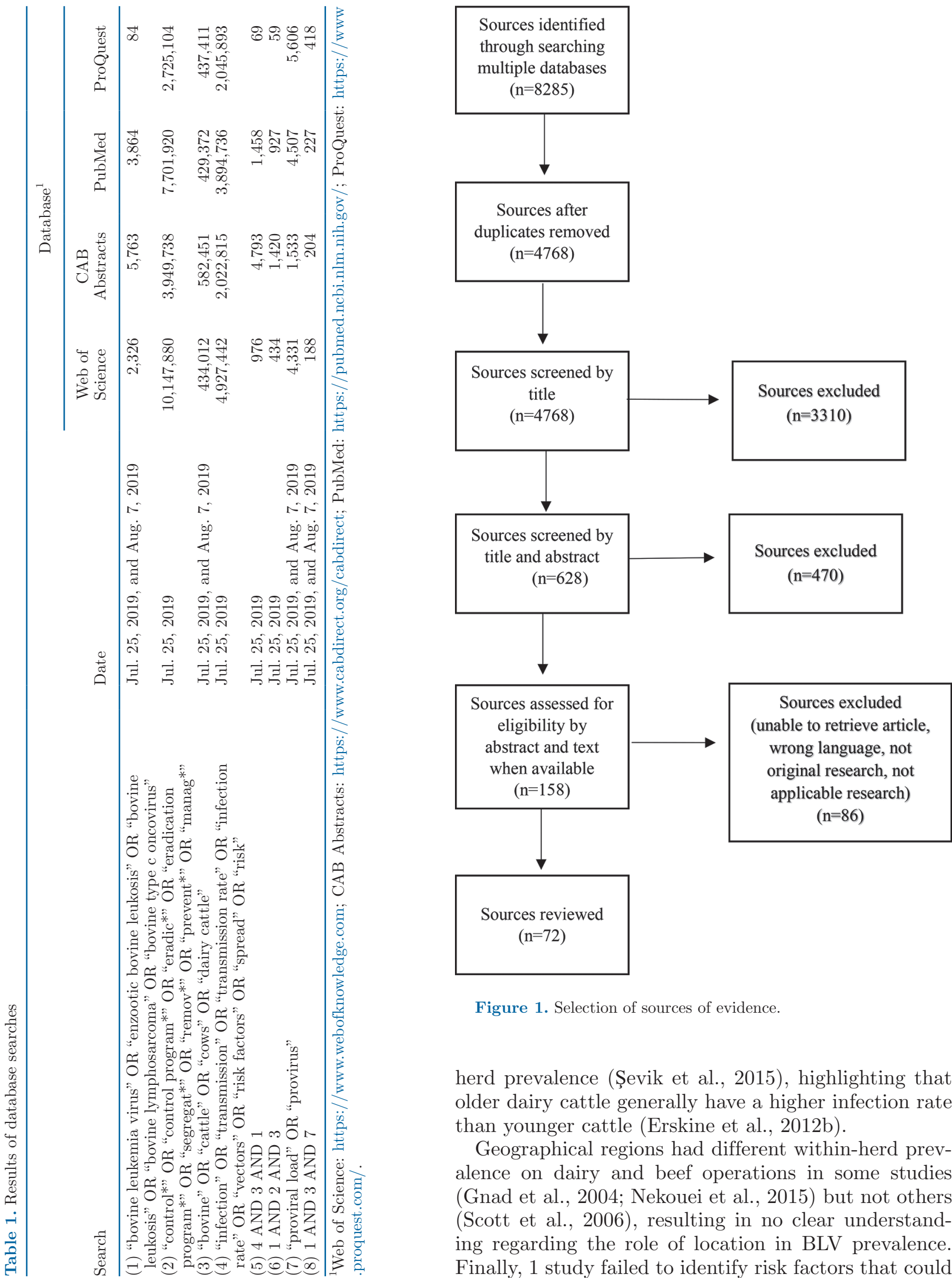

Figure 1. Selection of sources of evidence.

herd prevalence (Şevik et al., 2015), highlighting that older dairy cattle generally have a higher infection rate than younger cattle (Erskine et al., 2012b).

Geographical regions had different within-herd prevalence on dairy and beef operations in some studies (Gnad et al., 2004; Nekouei et al., 2015) but not others (Scott et al., 2006), resulting in no clear understanding regarding the role of location in BLV prevalence. Finally, 1 study failed to identify risk factors that could 


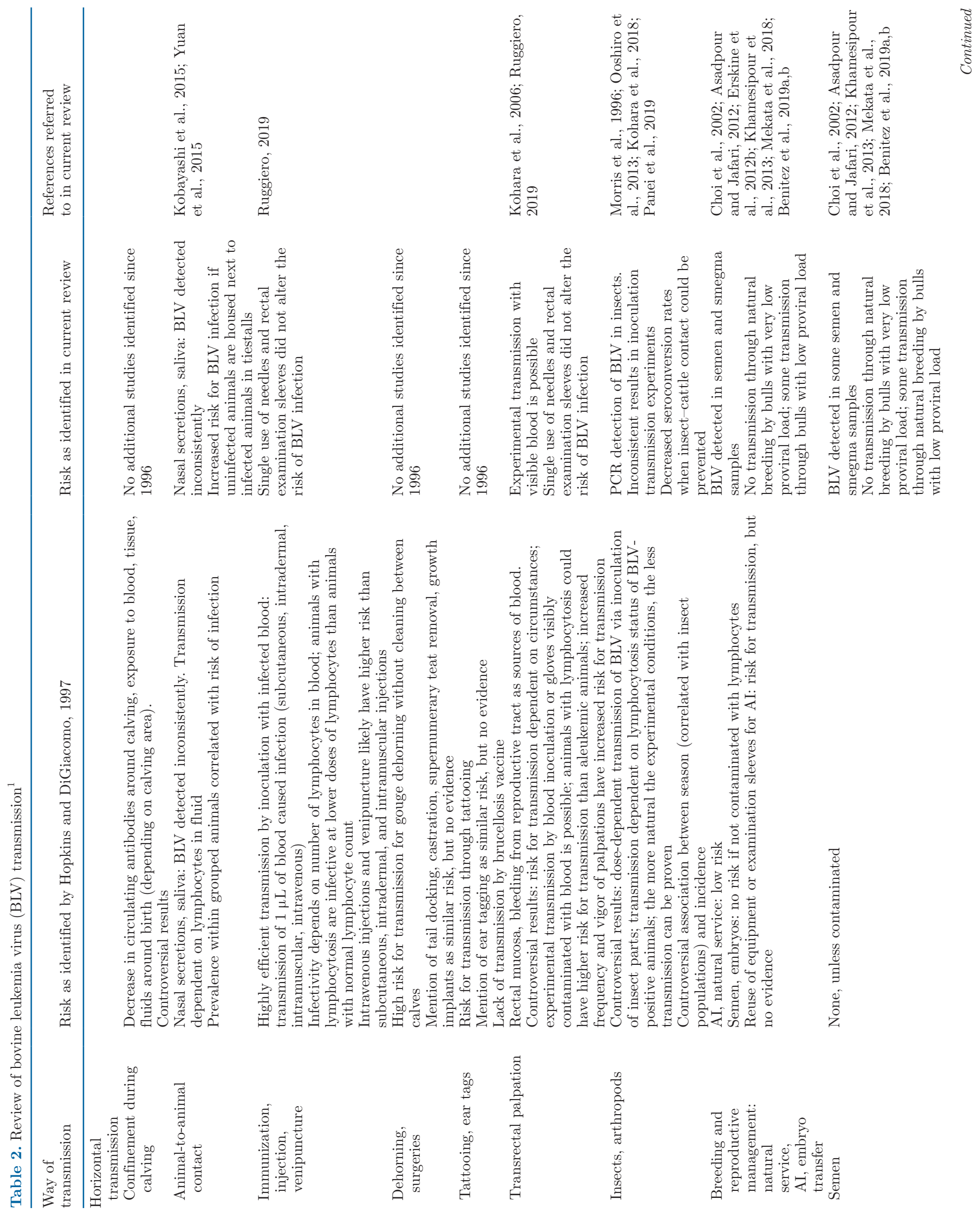




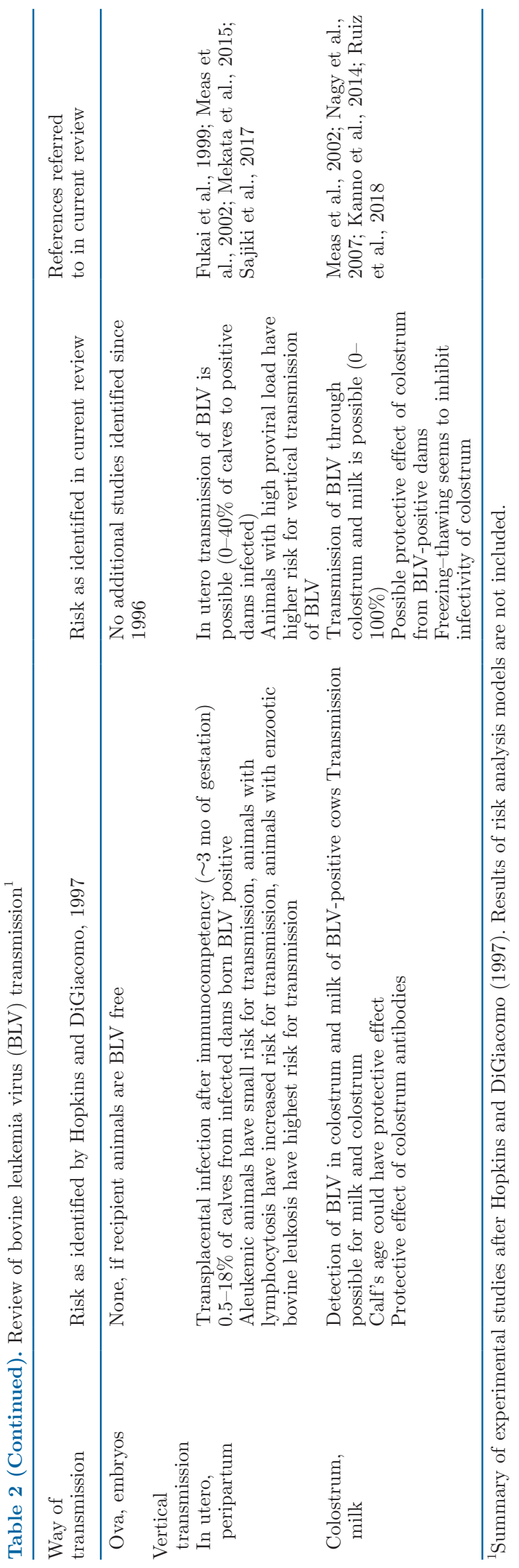

explain within-herd prevalence in beef herds (Bezerra et al., 2019), although only 16 herds were included.

Animal-to-Animal Contact. To determine the potential for virus transmission through nasal excretions or saliva, presence of BLV in these fluids was investigated. In a Japanese study (Yuan et al., 2015), Holstein-Friesian, Japanese Black, and crossbred cows were sampled and BLV provirus was detected in blood (35/50 PCR positive), nasal excretions (14/48 PCR positive), and saliva (6/47 PCR positive).

When housed in tiestalls, dairy cows neighboring BLV-positive cows had a higher risk of becoming test positive than those with BLV-negative neighbors (Kobayashi et al., 2015). However, no detailed information on cow management was provided in this publication. Therefore, it cannot be excluded that iatrogenic transmission or transmission by other factors caused BLV infection in this housing.

Additionally, the following risk factors for transmission were identified using risk analysis models: direct contact, especially in loose-housed dairy and beef cattle (Kobayashi et al., 2010, 2014), and intergenerational contact, such as exposure of heifers to older cattle in dairy herds (Sargeant et al., 1997). Contact between calves and adult cattle in beef herds, as well as commingling pregnant dairy heifers and adult dry dairy cows, increased within-herd BLV prevalence (Kobayashi et al., 2014). In addition, housing and on-farm management were associated with higher within-herd risk for BLV infection, including indoor housing of nonlactating dairy cows during winter (Sargeant et al., 1997), housing of dairy calves in hutches during the winter (Sargeant et al., 1997), or group feeding dairy heifers a TMR in communal feed bunks (Erskine et al., 2012a). Based on these findings, it is possible that the relevance of contact transmission of BLV among cattle has been underestimated.

Blood. Transmission of blood between cattle is generally recognized as an important risk factor for the spread of BLV, as low volumes of blood contain enough infected lymphocytes to transmit the virus.

Injections and Equipment. Reusing needles (Erskine et al., 2012a; Ramírez Vásquez et al., 2016), selenium injections given to nonlactating cows (Erskine et al., 2012a), and gouge dehorning were identified as BLV transmission risk factors via potential blood contamination (Kobayashi et al., 2010; Erskine et al., 2012a) on dairy operations in multiple cross-sectional risk analyses. However, vaccinations were associated with reduced prevalence to BLV on dairy farms in a cross-sectional risk analysis (Chi et al., 2002), perhaps acting as a surrogate measure for biosecurity.

Additionally, implementation of single-use needles for injections did not reduce risk of new seroconversions 
Kuczewski et al.: INVITED REVIEW: BOVINE LEUKEMIA VIRUS

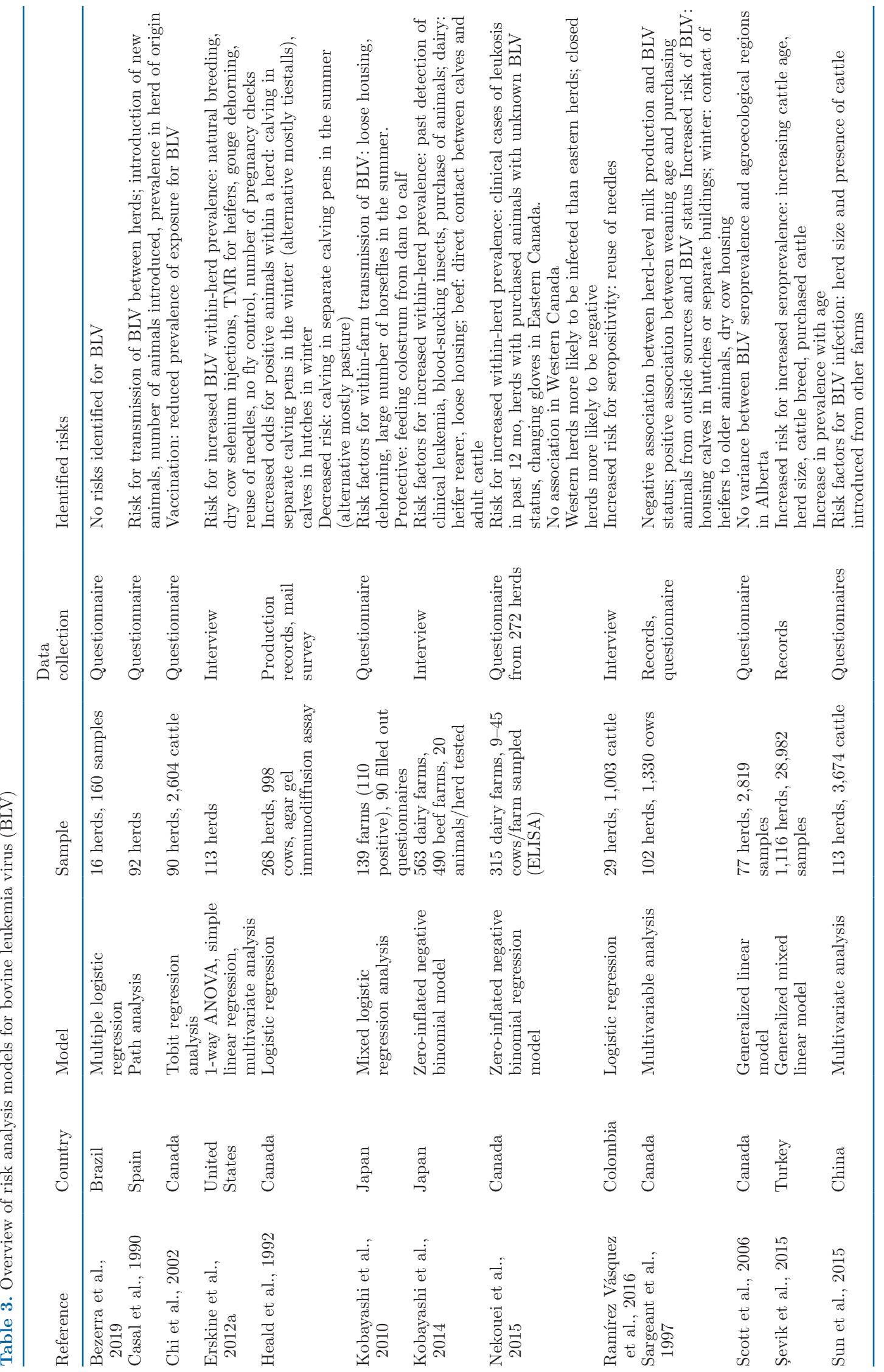


on 3 commercial dairies (Ruggiero, 2019). Even though individual cattle were tested and herds had varying within-herd prevalence $(25-74 \%)$, perhaps other (iatrogenic) transmission routes caused seroconversion, as details regarding management practices were missing. Transmission of BLV via blood is well-established route (Hopkins and DiGiacomo, 1997). However, it appears that only transitioning to single-use needles, thereby eliminating needles as a vehicle to transfer blood between cows, cannot decrease infection rates sufficiently to lower the within-herd prevalence.

Transrectal Palpation. Only 1 study (Kohara et al., 2006) investigated transrectal palpation as a mode of transmission for BLV. In that study, 3 of 4 BLVnegative Holstein-Friesian steers that were transrectally palpated $3 \mathrm{~min} / \mathrm{wk}$ for $4 \mathrm{wk}$, with the examiner wearing a palpation sleeve contaminated with BLV-positive blood, became BLV agar gel immunodiffusion test and PCR positive. No negative control animals were included. Generally, within-herd prevalence of dairy farms increases with increasing number of transrectal examinations (Erskine et al., 2012a). Although transmission of BLV via transrectal palpation is possible and contaminated palpation sleeves are considered a risk factor for BLV transmission, the probability of transmission of BLV under realistic on-farm circumstances remains unclear. Similarly, it is unclear whether implementation of single-use sleeves would reduce BLV status on dairy farms (Nekouei et al., 2015; Ruggiero, 2019).

Insects and Arthropods. The absence of fly control (Erskine et al., 2012a) or presence of blood-sucking insects on dairy and beef farms (Kobayashi et al., 2010, 2014) were identified as risk factors for BLV infection in cross-sectional risk analyses. Whereas this could be an indicator for BLV transmission via insects, it could also be a confounding factor for other on-farm factors influencing BLV transmission (e.g., general hygiene). Genetic material of BLV in biting flies can be detected by PCR (Panei et al., 2019); however, despite the presence of PCR-positive insects, natural transmission to Holstein or Aberdeen Angus steers and heifers was not confirmed (Panei et al., 2019). Additionally, there was no evidence of transmission following subcutaneous injection of a tick homogenate to sheep (Morris et al., 1996) and inconsistent transmission following injection (depth of injection not reported) of homogenized biting fly mouth parts (Panei et al., 2019). Although the role of biting flies in BLV transmission has been studied without yielding definitive answers, BLV seroconversion rates on dairy and beef farms were decreased when measures to decrease number of biting flies were implemented (Ooshiro et al., 2013; Kohara et al., 2018). Studies considering the role of other common biting and sucking insects (e.g., lice) are missing.
Natural Service. Hopkins and DiGiacomo (1997) concluded in their review that semen is not a source of BLV infection as long as it is not contaminated with BLV-infected lymphocytes. However, in a recent crosssectional study, natural breeding of dairy cattle was associated with higher within-herd BLV prevalence (Erskine et al., 2012a), although BLV status of herd bulls was unknown. Bovine leukemia virus has been detected in bull semen in some studies (Sharifzadeh et al., 2011; Asadpour and Jafari, 2012; Khamesipour et al., 2013) but not in others (Choi et al., 2002; Benitez et al., 2019b), representing a gap in knowledge regarding BLV transmission. In many of these reports, detailed assessment of techniques used was not possible; therefore, whether samples were contaminated with lymphocytes cannot be excluded. Additionally, BLV was detected in beef-bull smegma (Benitez et al., 2019b), implying a potential role in transmission during natural breeding. Finally, breeding beef and dairy bulls with low proviral loads (175.90 proviral copies $/ 10^{5}$ cells in smegma and $<100$ proviral copies/50 ng of genomic DNA in blood, respectively) were unable to transmit BLV (Mekata et al., 2018; Benitez et al., 2019a), whereas breeding dairy bulls with a higher proviral load (100-500 proviral copies/50 ng of genomic DNA in blood) were able to infect uninfected cattle (Mekata et al., 2018). Based on these findings, we inferred that transmission of BLV during natural breeding is possible; although it may not be caused by semen, it may be due to microabrasions and could depend on proviral loads in bulls.

\section{Vertical Transmission}

In Utero and Peripartum. Embryo transfer does not cause cow-to-cow transmission of BLV if done with appropriate precautions (e.g., single-use needles and transrectal examination sleeves; Fukai et al., 1999). Nonetheless, calves can generally acquire BLV from their dams through vertical transmission (Meas et al., 2002; Mekata et al., 2015). This was confirmed in a report (Sajiki et al., 2017) that BLV genomic sequences were identical in Holstein dams and their infected calves. Additionally, a cow's BLV proviral load influences rate of transmission to her calf. In 2 studies, dairy and beef cows with a high proviral load ( $>400$ copies $/ 10$ ng of DNA or $>3,000$ copies/50 ng of DNA) were more likely to transmit BLV to their calves than those with a lower proviral load $(<400$ copies/10 ng of DNA or $\leq 10$ copies/50 ng of DNA). Specifically, 14/29 and 4/4 calves were infected in the high proviral load groups versus $9 / 95$ and $0 / 2$ calves infected in the low proviral load groups (Mekata et al., 2015; Sajiki et al., 2017). Effects of proviral loads on likelihood of transmission 
could explain contradictory findings regarding vertical transmission of BLV (Hopkins and DiGiacomo, 1997).

Colostrum and Milk. Although transmission of BLV to calves via colostrum, milk, or both has been reported (Hopkins and DiGiacomo, 1997), quantification of the risk of BLV transmission via colostrum and milk remains a knowledge gap. Additionally, maternal antibodies may have a protective effect. Maternal antibodies in dairy calves that received colostrum and milk from BLV-positive dams were detectable until 3 to 9 mo of age (Meas et al., 2002; Nagy et al., 2007), which may prevent BLV infection (Nagy et al., 2007; Kobayashi et al., 2010). Although transmission from BLVpositive dairy cows to their calves was not detected in 15 BLV monoinfected dams, when cows were coinfected with both BLV and bovine immunodeficiency virus, 5/9 calves became and remained BLV positive based on PCR (Meas et al., 2002). Finally, in a small study, frozen-thawed cells from colostrum of $2 \mathrm{BLV}$-infected Holstein cows were rendered noninfectious for 1 sheep (Kanno et al., 2014). Although freezing and thawing of colostrum to prevent transmission of BLV to calves is commonly recommended (Ruiz et al., 2018), there is a lack of large-scale studies to support it.

\section{Experiences with Voluntary On-Farm BLV Control and Eradication}

As the effect of on-farm BLV control in dairy herds is generally determined by the fate of BLV-positive cattle, testing is critical. It enables identification of BLV-positive individuals and provides a measure of within-herd prevalence. Once BLV-positive cattle are identified, the 3 control strategies commonly used separately or in combination are (1) culling test-positive cattle, (2) physical segregation of test-positive and test-negative cattle in separate barns, pens within a barn, or pastures, and (3) implementation of BMP to reduce BLV transmission (Table 4).

Fourteen studies reported on effect of control in a single herd, whereas 9 studies reported outcomes in up to 9 herds. In the reported studies, BLV-infected cattle were detected with agar gel immunodiffusion test, ELISA, white blood cell counts, PCR, syncytia assay, RIA, and infectivity tests. It is noteworthy that test characteristics for diagnostic tests used will affect the accuracy of these prevalence estimations.

Unfortunately, studies describing culling and segregation approaches rarely provided details regarding timing of culling or segregation (Shettigara et al., 1986; Ruggiero, 2019). In addition, reported focus of management practices to prevent BLV transmission varied among studies (Table 5).
Of the 23 reviewed studies, 15 reported that eradication of BLV on farm was achieved successfully, whereby eradication was defined as failure to detect new BLVpositive cattle based on the test(s) used (details on definition for successful BLV control for each study can be found in Tables 4 and 5; Roberts and Bushnell, 1982; Kaja et al., 1984; Shettigara et al., 1986; Pannwitz et al., 1987; Brenner et al., 1988; Shettigara et al., 1989; Wang and Onuma, 1992; Yoshikawa et al., 1992; Mészáros et al., 1994; Molloy et al., 1994; Dereń et al., 2003; Suh et al., 2005; Lojkić et al., 2013; Ruggiero and Bartlett, 2019). Eradication was achieved by testing and culling (Roberts and Bushnell, 1982; Brenner et al., 1988; Molloy et al., 1994; Ruggiero and Bartlett, 2019); testing and segregation (Brenner et al., 1988; Yoshikawa et al., 1992); testing, culling, and segregation (Shettigara et al., 1986; Wang and Onuma, 1992; Dereń et al., 2003); a combination of testing, segregation, and management changes (Shettigara et al., 1989; Suh et al., 2005); implementation of culling and management strategies combined (Kaja et al., 1984); or combinations of culling, segregation, and management strategies (Pannwitz et al., 1987; Mészáros et al., 1994; Lojkić et al., 2013). The interval from the start of these studies to eradication ranged from 10 mo to 14 yr, whereas initial within-herd prevalence ranged from 2.2 to $70 \%$. Although lower within-herd prevalence generally seemed to hasten elimination of BLV, a low within-herd prevalence did not ensure rapid elimination of infection. It became apparent that BLV eradication can be a protracted progress. (Table 5). However, eradication of BLV may be possible despite high within-herd prevalence.

Of the remaining studies, several reported that a reduction in within-herd prevalence was achieved using the following approaches: testing and culling (Flensburg, 1976; Molloy et al., 1994; Ruggiero and Bartlett, 2019; Ruggiero et al., 2019); testing and segregating (Brenner et al., 1986); testing and management (Ferrer, 1982; Ruppanner et al., 1983; Sprecher et al., 1991); combinations of testing, culling, and segregating (Itoh et al., 1990; Ruggiero et al., 2019); or testing, segregating, and managing (Ferrer, 1982; Johnson et al., 1985). Finally, 2 studies reported no reduction or even an increase in within-herd prevalence despite implementation of testing and management or testing and culling approaches (Gutiérrez et al., 2011; Ruggiero and Bartlett, 2019).

Eradication and reduction of BLV prevalence seemed to be dependent on the commitment of the farmer toward BLV control (i.e., culling or segregation efforts, number of BMP implemented). The more control efforts were implemented, the more efficient BLV control 


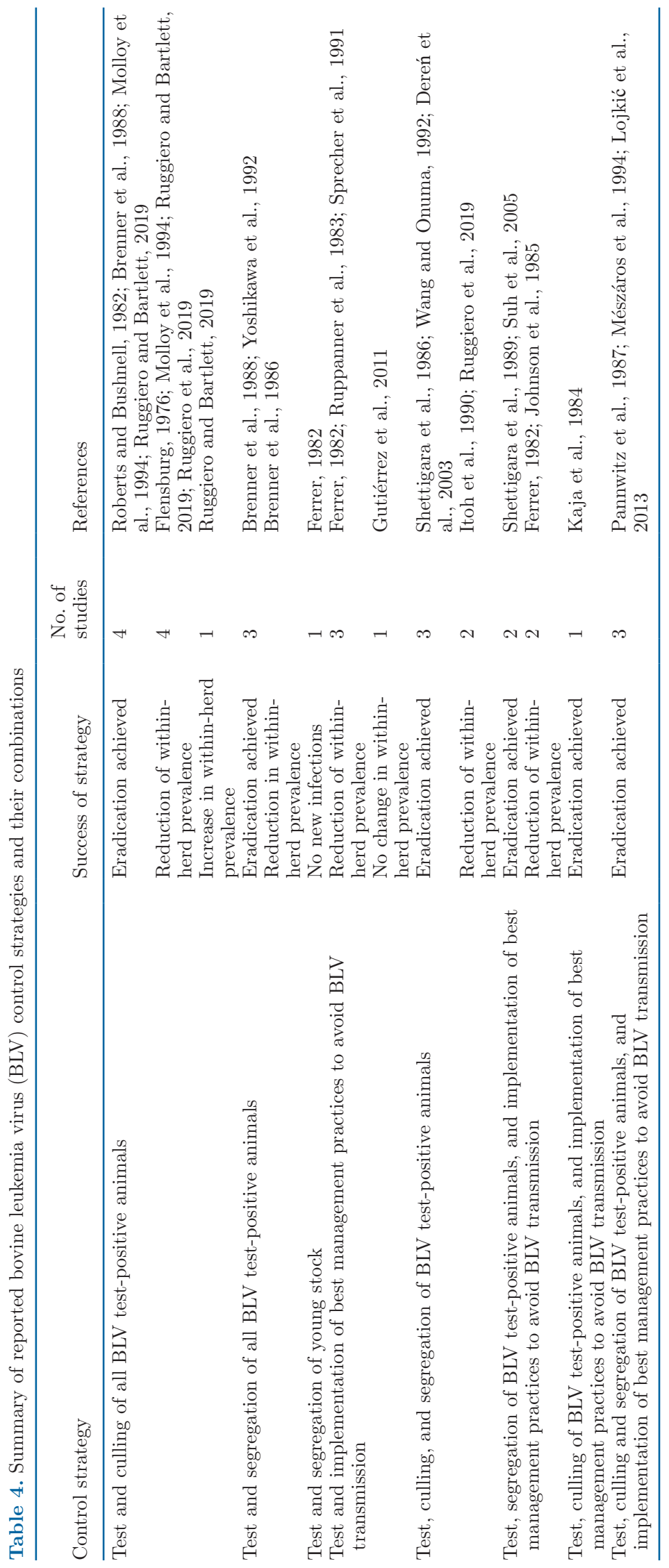


Kuczewski et al.: INVITED REVIEW: BOVINE LEUKEMIA VIRUS

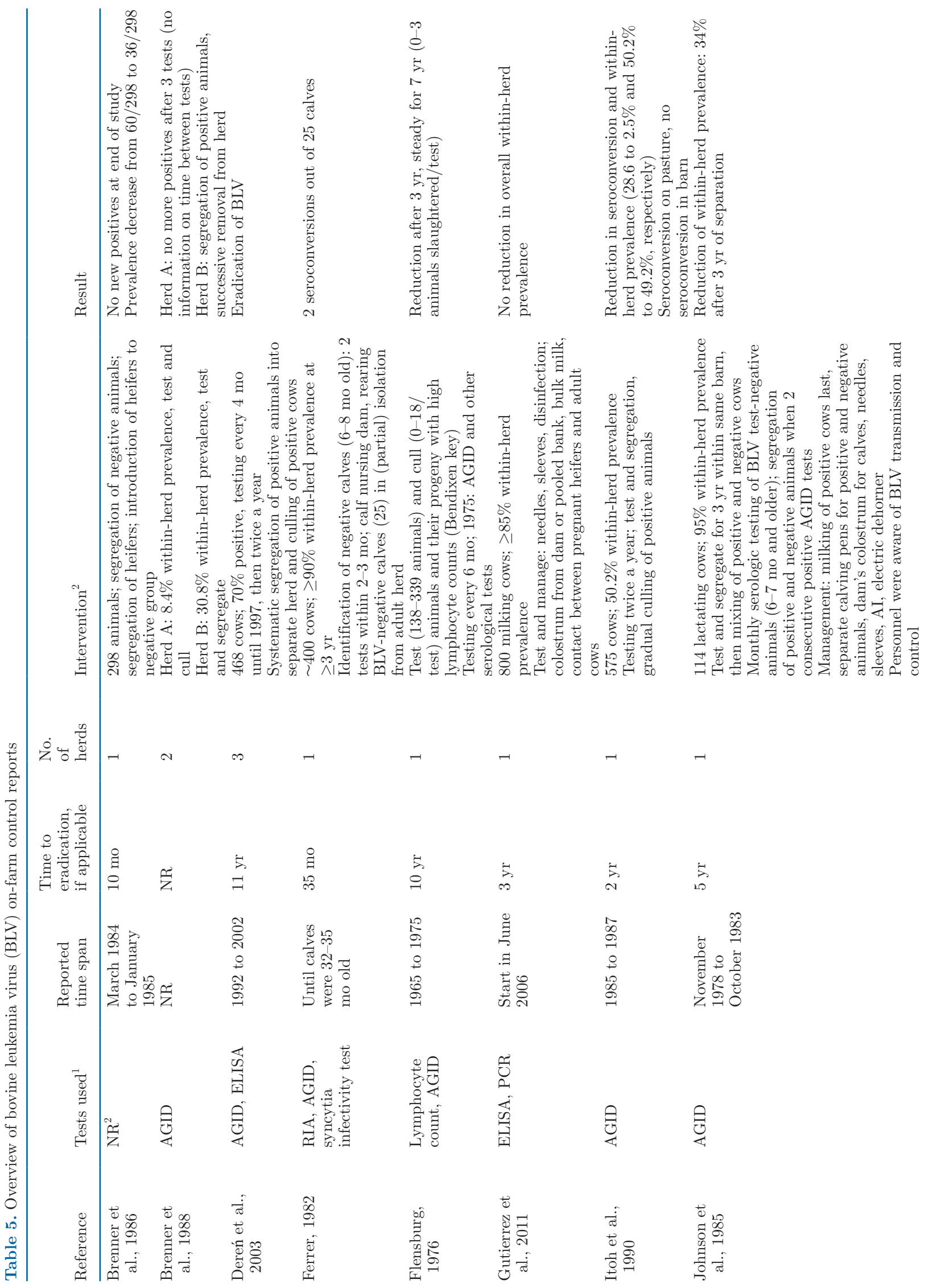




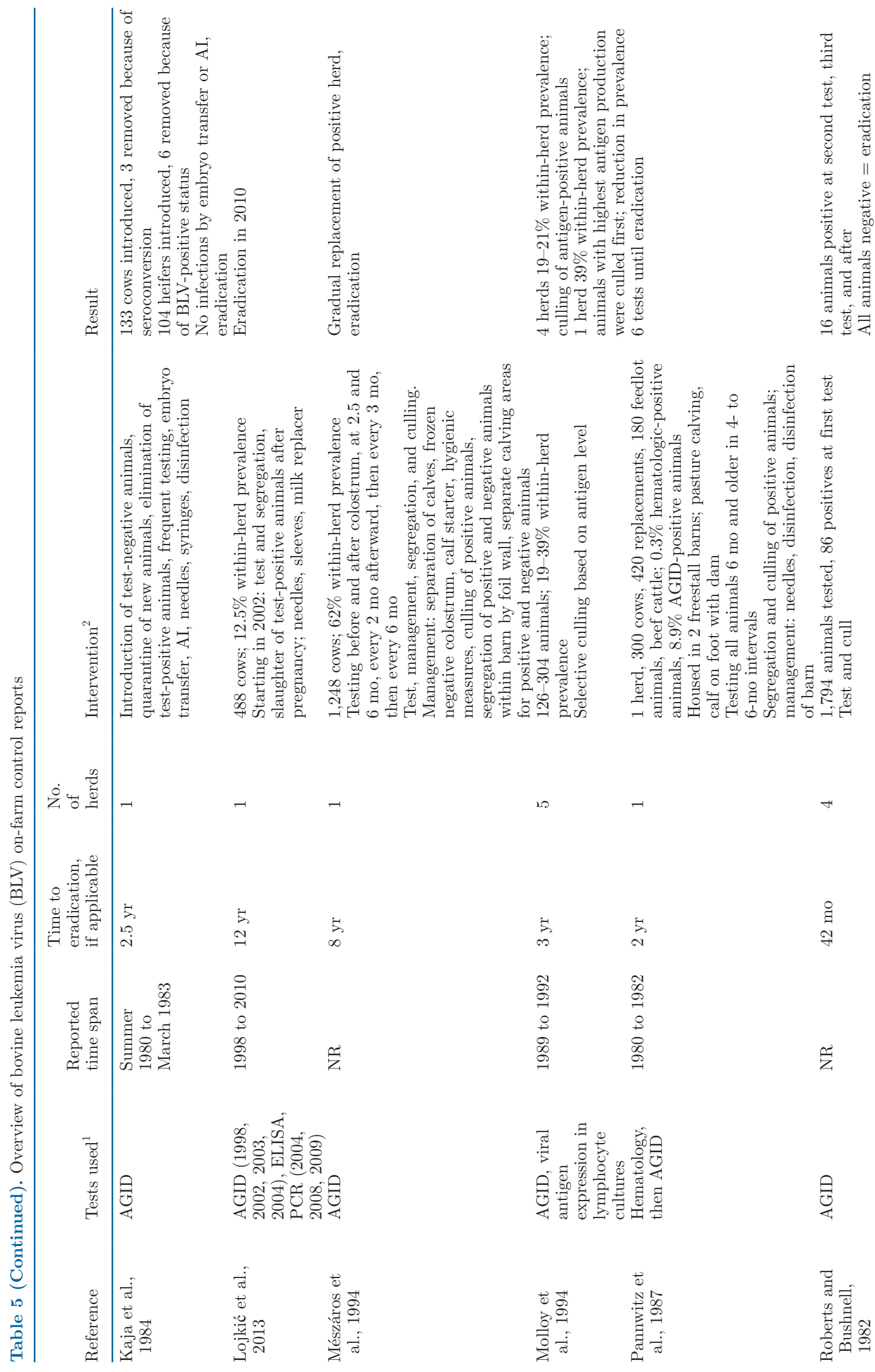




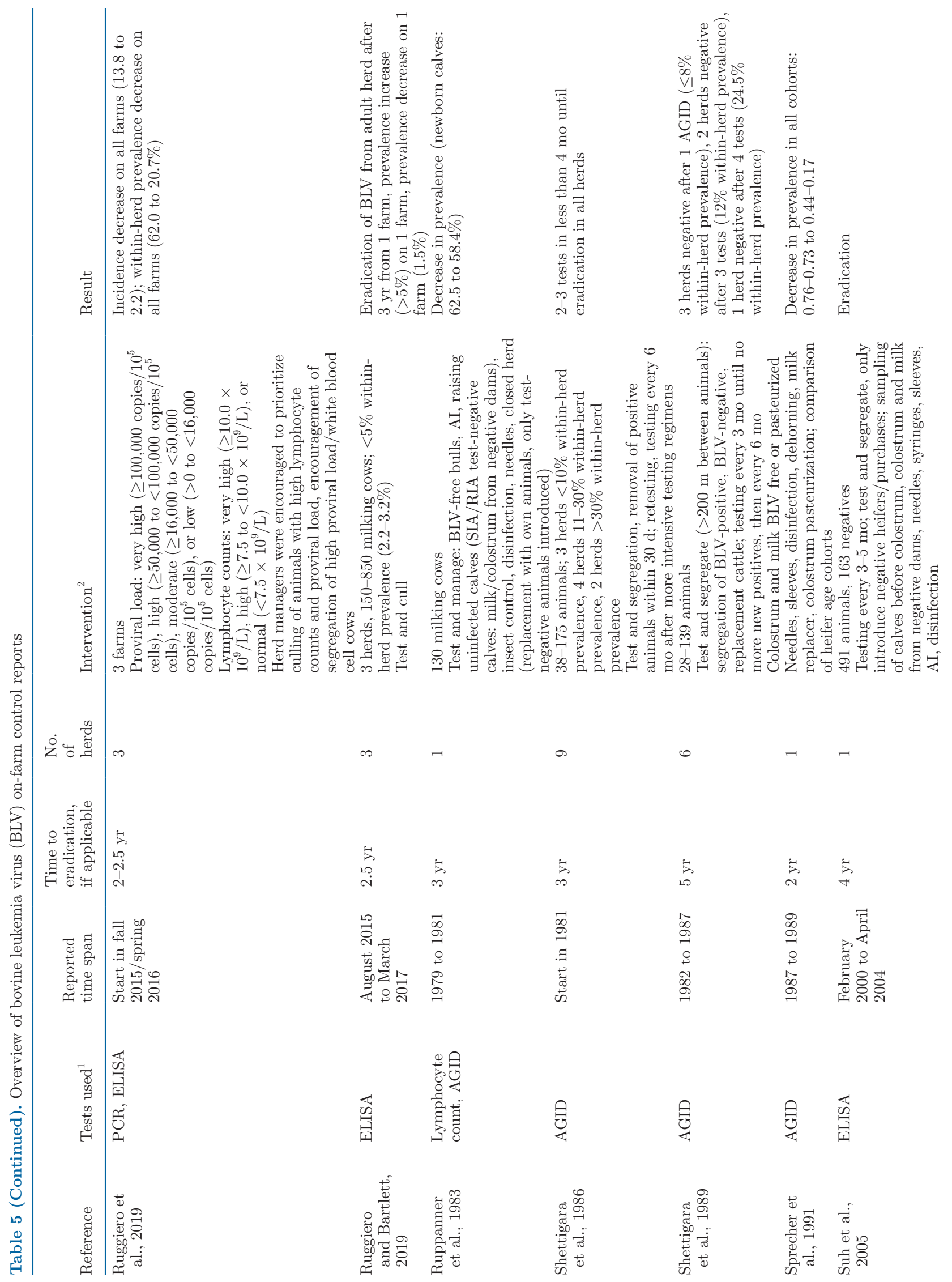


Kuczewski et al.: INVITED REVIEW: BOVINE LEUKEMIA VIRUS

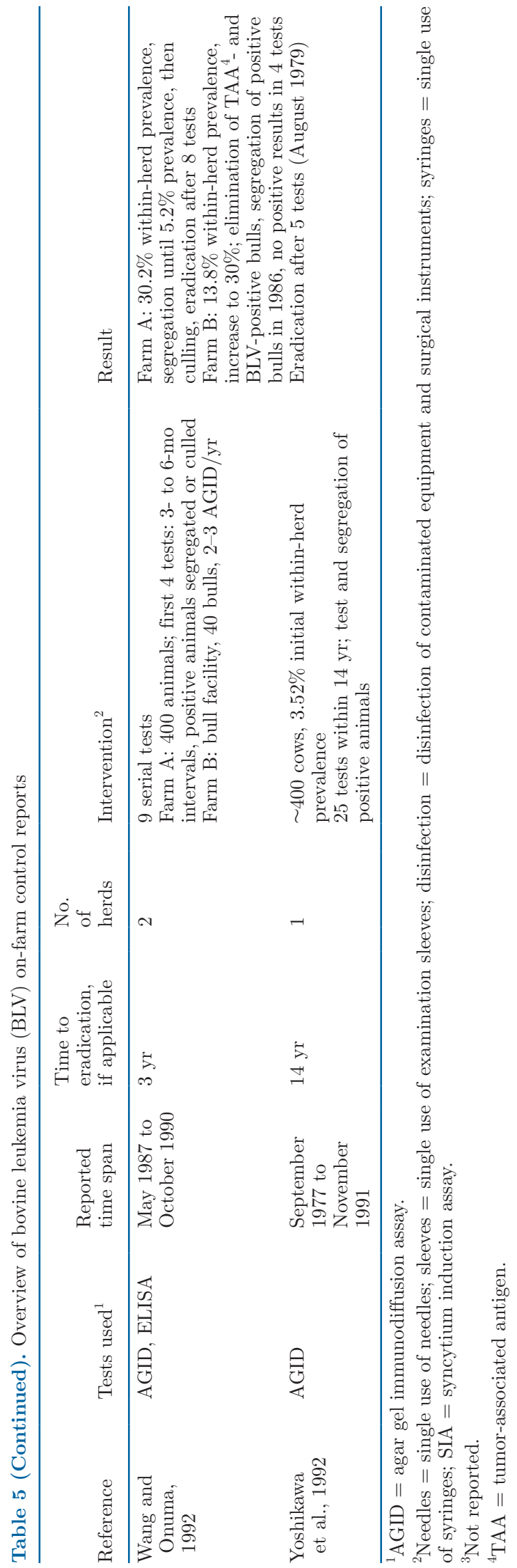

seemed to be, although uncontrollable or unknown factors might disrupt eradication efforts.

\section{BLV Proviral Load}

Effects of proviral load in BLV-infected cattle on transmission dynamics have recently received increased interest. The findings were considered relevant to onfarm BLV control, especially in situations where the prevalence at the start of a control program is relatively high. It could provide an alternative or addition to the above-mentioned strategies. Therefore, a summary of these findings was included in the present review and is presented here.

Early on, it became clear that cattle with lymphocytosis, EBL, or both have higher risk of transmitting BLV to uninfected cattle (Kettmann et al., 1980). Lymphocytic cattle had higher absolute lymphocyte counts than nonlymphocytic cattle, whereby 25 to $35 \%$ of circulating lymphocytes had integrated proviruses. In contrast, in cows without lymphocytosis, only $5 \%$ of circulating lymphocytes had integrated proviruses. Therefore, the blood volume needed from cattle with lymphocytosis to infect other cattle was smaller compared with the volume needed from cattle without lymphocytosis (Buxton and Schultz, 1984).

These findings were followed by multiple studies that evaluated the BLV proviral load in infected animals. Numerous ways to measure and express proviral load were used: copies per $50 \mathrm{ng}$ of DNA (Sajiki et al., 2017; Mekata et al., 2018), copies per microgram of DNA (Juliarena et al., 2007), copies per $10^{5}$ cells (Benitez et al., 2019a,b; Kobayashi et al., 2019; Ruggiero et al., 2019), percentage of peripheral white blood cells infected (Alvarez et al., 2013; Gutiérrez et al., 2014; Merlini et al., 2016), and relative proviral load compared with 18S reference gene (Gutiérrez et al., 2011, 2012, 2015).

To date, reliable identification of cattle with a high proviral load was dependent on relatively expensive PCR-based methods, hindering utilization (Leach et al., 2010; Sorge et al., 2010). Fortunately, an ELISAbased antibody titration has potential as a cheaper alternative, as p24 (BLV antigen) antibody titers are directly correlated with proviral load (Gutiérrez et al., 2012). Additionally, ELISA optical density values were directly correlated with the negative production effects of BLV infection (Norby et al., 2016). Another cost-effective approach may be blood cell differentiation, whereby increased white blood cell counts could be used as indicators for high proviral loads (Alvarez et al., 2013; Nishiike et al., 2016).

Despite these differences in approaches, it became clear that infected cattle harbor variable amounts of provirus in their cells, generally expressed as low to 
high proviral loads. This information was considered important because cattle with a high proviral load may be more likely to infect others, whereas cattle with a low proviral load are very unlikely to infect others (Jimba et al., 2010).

It is still unclear whether proviral load within an infected animal remains constant once established (Gutiérrez et al., 2014; Merlini et al., 2016) or whether it can change over time (Ohno et al., 2015; Nishiike et al., 2016), as the proviral load may increase as individuals progress from aleukemic to lymphocytic stages (Ohno et al., 2015). Nonetheless, BLV-infected cattle with a high proviral load were more likely to develop lymphocytosis, progress to EBL, or both (Jimba et al., 2010; Nishiike et al., 2016; Kobayashi et al., 2019), Similarly, although cattle can have a high proviral load and a normal lymphocyte count (Juliarena et al., 2007), cattle with lymphocytosis likely have a higher proviral load than those with a normal white blood cell count (Juliarena et al., 2007; Alvarez et al., 2013; Ohno et al., 2015; Nakada et al., 2018; Benitez et al., 2019b).

Some studies were conducted to better understand the role of proviral load for the risk of transmission of BLV between animals. As described previously, dams with a high proviral load have a higher probability of infecting their calves in utero or peripartum than those with a lower proviral load (Mekata et al., 2015; Sajiki et al., 2017), and they have increased levels of provirus as well as anti-BLV antibodies in their colostrum (Gutiérrez et al., 2015) compared with those with a low proviral load. However, a negative correlation between proviral load and BLV antibody titers in milk was reported (Jaworski et al., 2016). To elucidate practical ramifications of proviral loads for on-farm BLV control, 2 kinds of studies were conducted: (1) cattle with a low proviral load were introduced into a herd of BLV test-negative cattle, or (2) cattle with a high proviral load were removed from a BLV-infected herd and BLV seroconversion rates and within-herd prevalence were monitored. Regarding outcomes, introduction of low proviral load bulls (Mekata et al., 2018; Benitez et al., 2019a) or cows caused no or only a few new infections in BLV test-negative cows and heifers (Juliarena et al., 2016). In addition, removal of individuals with a high proviral load in 3 commercial dairy herds decreased BLV seroconversion rate and BLV within-herd prevalence within 2.5 yr (Ruggiero et al., 2019). Although more research is needed to recommend the use of proviral load monitoring to inform management decisions, it could be a valuable addition to future on-farm BLV control.

\section{DISCUSSION}

The objective of this review was to discuss the available literature on BLV transmission and control efforts published since 1995 as well as to elucidate potential utility of proviral load in future control BLV control programs. Additionally, gaps in knowledge were identified. Seventy-two studies published after the review on BLV by Hopkins and DiGiacomo (1997) were included in this paper. Despite the resulting limited temporal scope of the present review, it was considered beneficial to summarize the most recent research on BLV transmission and control.

In general, results of studies concerning transmission of BLV before and after 1995 are not in conflict, whereby knowledge gaps identified by Hopkins and DiGiacomo (1997) still remain relevant. Moreover, it was noted that many studies did not report enough information for a thorough evaluation of applied methods or participating herds' circumstances, precluding realistic assessment of study quality. Even though various models have been created to identify transmission risk factors, the resulting information is still limited. Nonetheless, identified risk factors in models agreed to a large extent with identified and examined routes of transmission in other observational studies. Additionally, results of risk analyses have highlighted a potential role of animal-toanimal contact for transmission of BLV that warrant further investigation.

Thus far, successful BLV eradication was only reported when culling or segregation strategies were applied. However, diagnostic methodologies have improved over time (Beier and Siakkou, 1994; Rola-Łuszczak et al., 2013). Therefore, studies using tests with low sensitivity (e.g., agar gel immunodiffusion test) may have missed individuals that would have been identified as positive with the current more sensitive methods (e.g., ELISA) and therefore incorrectly reported successful BLV eradication. Likewise, eradication efforts could be accelerated with modern serological methods or molecular diagnostics (e.g., PCR), as BLV-positive cattle can be identified more reliably and sooner after infection. Therefore, time frames documented in historical eradication studies may no longer be relevant and the true effect of control strategies may have not been accurately measured. Additionally, none of the studies demonstrated that solely implementing management practices resulted in eradication of BLV from the farm. However, unfortunately, none of the studies monitored herds long enough to provide a definitive answer on whether eradication of BLV on farm was possible with only BMP. Other studies reported no change or an 
increase in within-herd prevalence despite implementation of BMP (Gutiérrez et al., 2011; Ruggiero, 2019). Perhaps transmission prevention through BMP was incomplete, either because some transmission routes have not yet been identified or because not all necessary control measures were implemented.

In addition, the dairy industry has profoundly changed since the majority of the described BLV control studies were conducted. Consequently, it is important to consider whether the published literature remains relevant. Despite changes in the dairy industry, the most common management practices have remained the same. For example, milking practices are generally similar, although there are more vaccinations and hormone treatments as well as ongoing increases in herd size. Additionally, as technology becomes more sophisticated and affordable, calf management, milking, and other practices change. For example, milk and colostrum are frequently pasteurized before feeding to calves, and milking procedures follow more hygienic protocols (Barkema et al., 2015). Although some risk factors could have increased in importance (e.g., needles, animal-toanimal contact), other transmission factors could lose their relevance (e.g., colostrum and milk). Hence, to make definitive recommendations, large-scale, longitudinal studies focusing on relevant transmission routes (e.g., colostrum, milk, tools, animal-to-animal contact) and on-farm BLV eradication based on implementation of BMP are necessary. In addition, the importance of biosecurity measures should be highlighted. By implementing biosecurity protocols (e.g., establishment of a closed herd), introduction of BLV into a herd could be avoided and implemented BLV control measures would not be undermined.

Additionally, multiple studies expounded on the apparent relevance of proviral load for progression of the disease to lymphocytosis, EBL, or both as well as on transmission of BLV among cattle (Mekata et al., 2015; Benitez et al., 2019a; Kobayashi et al., 2019). Consistent reporting on measurement of BLV proviral load would make comparisons more relevant (Juliarena et al., 2016; Ruggiero et al., 2019). Additionally, by taking proviral load into account, some of the contradictory results of the described observational studies (e.g., transmission of BLV through colostrum or transrectal palpation in only some cases) may be explained.

Finally, eradication attempts could be further accelerated by genetic selection for BLV-resistant cattle (Juliarena et al., 2008; Esteban, 2009), as BoLA class II haplotypes appear to modulate risk of developing high proviral loads and some cattle are therefore at a lower risk of progressing to lymphocytosis and EBL. Regardless, as altering genetic composition of an entire herd is generally time consuming and complex, it should only be considered as part of a long-term strategy.

\section{CONCLUSIONS}

The review of the available literature concerning control of BLV resulted in the conclusion that knowledge as well as knowledge gaps have remained consistent over time. Although the main known BLV transmission routes (blood, in utero, colostrum, milk) were supported, risks connected with specific management practices within dairy operations (e.g., hoof trimming, feeding raw milk) remained inconclusive. Moreover, other transmission routes might remain unidentified, perhaps accounting for unsuccessful control attempts, highlighting the limited body of literature available for BLV control. Additionally, the role of proviral load information for on-farm BLV control deserves further attention. This method appears promising, especially in herds with high prevalence, where the sole change of management may not eliminate BLV. Nonetheless, more studies are needed to fill knowledge gaps in BLV transmission and understand the importance of proviral load for on-farm BLV control.

\section{ACKNOWLEDGMENTS}

The authors acknowledge the assistance of John Kastelic (Department of Production Animal Health, University of Calgary, Calgary, AB, Canada) in editing the manuscript. This study was funded by Alberta Milk (Edmonton, AB, Canada) and the Alberta Livestock and Meat Agency/Alberta Agriculture and Forestry (Edmonton, AB, Canada). The authors have not stated any conflicts of interest.

\section{REFERENCES}

Alvarez, I., G. Gutierrez, M. Gammella, C. Martinez, R. Politzki, C. Gonzalez, L. Caviglia, H. Carignano, N. Fondevila, M. Poli, and K. Trono. 2013. Evaluation of total white blood cell count as a marker for proviral load of bovine leukemia virus in dairy cattle from herds with a high seroprevalence of antibodies against bovine leukemia virus. Am. J. Vet. Res. 74:744-749. https://doi.org/10 $.2460 /$ ajvr.74.5.744.

Asadpour, R., and R. Jafari. 2012. Detection of bovine leukosis provirus in blood and semen samples of bulls. Comp. Clin. Pathol. 21:187-191. https://doi.org/10.1007/s00580-010-1083-5.

Barkema, H. W., M. A. G. von Keyserlingk, J. P. Kastelic, T. J. G. M. Lam, C. Luby, J. P. Roy, S. J. LeBlanc, G. P. Keefe, and D. F. Kelton. 2015. Invited review: Changes in the dairy industry affecting dairy cattle health and welfare. J. Dairy Sci. 98:7426-7445. https://doi.org/10.3168/jds.2015-9377.

Bartlett, P. C., L. M. Sordillo, T. M. Byrem, B. Norby, D. L. Grooms, C. L. Swenson, J. Zalucha, and R. J. Erskine. 2014. Options for the control of bovine leukemia virus in dairy cattle. J. Am. Vet. Med. Assoc. 244:914-922. https://doi.org/10.2460/javma.244.8.914. 
Beier, D., and H. Siakkou. 1994. A comparison of serological tests for the diagnosis of enzootic bovine leukosis and eradication of infection from a large herd. Tierarztl. Umsch. 49:356-360.

Benitez, O. J., J. N. Roberts, B. Norby, P. C. Bartlett, J. E. Maeroff, and D. L. Grooms. 2019a. Lack of bovine leukemia virus transmission during natural breeding of cattle. Theriogenology 126:187190. https://doi.org/10.1016/j.theriogenology.2018.12.005.

Benitez, O. J., J. N. Roberts, B. Norby, P. C. Bartlett, S. N. Takeshima, S. Watanuki, Y. Aida, and D. L. Grooms. 2019b. Breeding bulls as a potential source of bovine leukemia virus transmission in beef herds. J. Am. Vet. Med. Assoc. 254:1335-1340. https://doi .org/10.2460/javma.254.11.1335.

Bezerra, N. P. C., D. C. Bezerra, H. P. Santos, H. M. Pereira, and A. L. A. Silva. 2019. Risk factors analysis applied to antibodies to bovine herpesvirus type 1, bovine viral diarrhea virus, bovine leukemia virus and Brucella abortus among cattle: A cross-sectional study. Acta Vet. Brasilica 13:5-12. https://doi.org/10.21708/avb .2019.13.1.7818.

Brenner, J., R. Meirom, R. Avraham, D. Savir, G. Hoida, and Z. Trainin. 1986. Interim results of a bovine leukaemia virus (BLV) eradication programme in a Kibbutz dairy herd. Refu. Vet. 42:53.

Brenner, J., R. Meirom, R. Avraham, S. Savir, and Z. Trainin. 1988. Trial of two methods for the eradication of bovine leucosis virus infection from two large dairy herds in Israel. Refu. Vet. 44:168-175.

Brunner, M. A., D. H. Lein, and E. J. Dubovi. 1997. Experiences with the New York State bovine leukosis virus eradication and certification program. Vet. Clin. North Am. Food Anim. Pract. 13:143-150. https://doi.org/10.1016/S0749-0720(15)30369-8.

Burki, F. 1982. Experiences gained and progress achieved with BLV [bovine leukosis virus] elimination from Austrian livestock. Pages 516-528 in Fourth International Symposium on Bovine Leukosis, Bologna, Italy. O. C. Straub, ed. Martinus Nijhoff, The Hague, the Netherlands.

Buxton, B. A., and R. D. Schultz. 1984. Factors affecting the infectivity of lymphocytes from cattle with bovine leukosis virus. Can. J. Comp. Med. 48:365-369.

Canadian Food Inspection Agency. 2003. Canada Health Accredited Herd (CHAH). Accessed Aug. 27, 2019. https://www.inspection.gc .ca/animals/terrestrial-animals/diseases/accredited-veterinarian-s -manual/eng/1343915611518/1343915703253.

Casal, J., P. Learte, and E. Torre. 1990. A path model of factors influencing bovine leukemia virus transmission between cattle herds. Prev. Vet. Med. 10:47-61. https://doi.org/10.1016/0167 $-5877(90) 90050-\mathrm{R}$.

Chi, J., J. A. VanLeeuwen, A. Weersink, and G. P. Keefe. 2002. Management factors related to seroprevalences to bovine viral-diarrhoea virus, bovine-leukosis virus, Mycobacterium avium subspecies paratuberculosis, and Neospora caninum in dairy herds in the Canadian Maritimes. Prev. Vet. Med. 55:57-68. https://doi.org/10 .1016/S0167-5877(02)00067-3.

Choi, K. Y., D. Monke, and J. L. Stott. 2002. Absence of bovine leukosis virus in semen of seropositive bulls. J. Vet. Diagn. Invest. 14:403-406. https://doi.org/10.1177/104063870201400507.

Dereń, W., A. Szewczyk-Sadowska, and J. Rulka. 2003. The eradication of enzootic bovine leucosis in a large farm population. Pol. J. Vet. Sci. 6(Suppl.):12-14.

EFSA AHAW Panel. 2015. Scientific opinion on enzootic bovine leukosis. EFSA J. 13:4188. https://doi.org/10.2903/j.efsa.2015.4188.

Erskine, R. J., P. C. Bartlett, T. M. Byrem, C. L. Render, C. Febvay, and J. T. Houseman. 2012a. Herd-level determinants of bovine leukaemia virus prevalence in dairy farms. J. Dairy Res. 79:445-450. https://doi.org/10.1017/S0022029912000520.

Erskine, R. J., P. C. Bartlett, T. M. Byrem, C. L. Render, C. Febvay, and J. T. Houseman. 2012b. Using a herd profile to determine age-specific prevalence of bovine leukemia virus in Michigan dairy herds. Vet. Med. Int. 2012:350374. https://doi.org/10.1155/2012/ 350374 .

Esteban, E. 2009. Bovine leukemia virus proposed control and eradication programs by marker assisted breeding of genetically resistant cattle. Chapter 6 in Animal Genetics. L. J. Rechi, ed. Nova Science Publishers Inc., Hauppauge, NY.
European Commission. 2015. Bovine and swine diseases 2014 annual report. Accessed May 1, 2019. https://ec.europa.eu/food/sites/ food/files/animals/docs/la_bovine_final_report_2014.pdf.

Ferrer, J. F. 1982. Eradication of bovine leukemia virus infection from a high-prevalence herd, using radioimmunoassay for identification of infected animals. J. Am. Vet. Med. Assoc. 180:890-893.

Flensburg, I. C. 1976. Attempt to eradicate leukosis from a dairy herd by slaughter of cattle with lymphocytosis. Report over a ten year period. Vet. Microbiol. 1:301-305. https://doi.org/10.1016/0378 -1135(76)90034-1.

Frie, M. C., and P. M. Coussens. 2015. Bovine leukemia virus: A major silent threat to proper immune responses in cattle. Vet. Immunol. Immunopathol. 163:103-114. https://doi.org/10.1016/j.vetimm .2014.11.014.

Fukai, K., M. Sato, M. Kawara, Z. Hoshi, S. Ueno, N. Chyou, and H. Akashi. 1999. A case of an embryo transfer calf infected with bovine leukemia virus from the recipient cow. Zentralbl. Veterinarmed. B 46:511-515. https://doi.org/10.1111/j.1439-0450.1999 .tb01243.x.

Gnad, D. P., J. M. Sargeant, P. J. Chenoweth, and P. H. Walz. 2004. Prevalence of bovine leukemia virus in young, purebred beef bulls for sale in Kansas. Int. J. Appl. Res. Vet. Med. 2:215-219.

Goff, S. P. 2013. Retroviridae. Pages 1424-1473 in Fields Virology. 6th ed. B. N. Fields, D. M. Knipe, and P. M. Howley, ed. Wolters Kluwer Health/Lippincott Williams \& Wilkins, Philadelphia, PA.

Gutiérrez, G., I. Alvarez, R. Merlini, F. Rondelli, and K. Trono. 2014 Dynamics of perinatal bovine leukemia virus infection. BMC Vet. Res. 10:82. https://doi.org/10.1186/1746-6148-10-82.

Gutiérrez, G.. I. Alvarez, R. Politzki, M. Lomonaco, M. J. Dus Santos, F. Rondelli, N. Fondevila, and K. Trono. 2011. Natural progression of Bovine Leukemia Virus infection in Argentinean dairy cattle. Vet. Microbiol. 151:255-263. https://doi.org/10.1016/j.vetmic .2011.03.035.

Gutiérrez, G., H. Carignano, I. Alvarez, C. Martinez, N. Porta, R. Politzki, M. Gammella, M. Lomonaco, N. Fondevila, M. Poli, and K. Trono. 2012. Bovine leukemia virus p24 antibodies reflect blood proviral load. BMC Vet. Res. 8:187. https://doi.org/10.1186/1746 $-6148-8-187$.

Gutiérrez, G., M. Lomonaco, I. Alvarez, F. Fernandez, and K. Trono. 2015. Characterization of colostrum from dams of BLV endemic dairy herds. Vet. Microbiol. 177:366-369. https://doi.org/10.1016/ j.vetmic.2015.03.001

Heald, M. T. S., D. Waltner-Toews, R. M. Jacobs, and W. Bruce McNab. 1992. The prevalence of anti-bovine leukemia virus antibodies in dairy cows and associations with farm management practices, production and culling in Ontario. Prev. Vet. Med. 14:45-55. https://doi.org/10.1016/0167-5877(92)90083-R.

Hopkins, S. G., and R. F. DiGiacomo. 1997. Natural transmission of bovine leukemia virus in dairy and beef cattle. Vet. Clin. North Am. Food Anim. Pract. 13:107-128. https://doi.org/10.1016/ S0749-0720(15)30367-4.

Itoh, H., N. Ogasawara, K. Ohshima, K. Okada, S. Numakunai, and Y. Seimiya. 1990. An attempt to eradicate bovine leukaemia virus infection in a public pasture. Nippon Juigaku Zasshi 52:661-663. https://doi.org/10.1292/jvms1939.52.661.

Jaworski, J. P., N. G. Porta, G. Gutierrez, R. P. Politzki, I. Alvarez, R. Galarza, A. Abdala, L. Calvinho, and K. G. Trono. 2016. Short communication: Relationship between the level of bovine leukemia virus antibody and provirus in blood and milk of cows from a naturally infected herd. J. Dairy Sci. 99:5629-5634. https://doi.org/10 .3168/jds.2015-10813.

Jimba, M., S. Takeshima, K. Matoba, D. Endoh, and Y. Aida. 2010. BLV-CoCoMo-qPCR: Quantitation of bovine leukemia virus proviral load using the CoCoMo algorithm. Retrovirology 7:91. https: //doi.org/10.1186/1742-4690-7-91.

Johnson, R., C. D. Gibson, and J. B. Kaneene. 1985. Bovine leukemia virus: A herd-based control strategy. Prev. Vet. Med. 3:339-349. https://doi.org/10.1016/0167-5877(85)90011-X.

Juliarena, M. A., C. N. Barrios, M. C. Ceriani, and E. N. Esteban. 2016. Hot topic: Bovine leukemia virus (BLV)-infected cows with low proviral load are not a source of infection for BLV-free cat- 
tle. J. Dairy Sci. 99:4586-4589. https://doi.org/10.3168/jds.2015 -10480 .

Juliarena, M. A., S. E. Gutierrez, and C. Ceriani. 2007. Determination of proviral load in bovine leukemia virus-infected cattle with and without lymphocytosis. Am. J. Vet. Res. 68:1220-1225. https:// doi.org/10.2460/ajvr.68.11.1220.

Juliarena, M. A., M. Poli, L. Sala, C. Ceriani, S. Gutierrez, G. Dolcini, E. M. Rodrguez, B. Mario, C. Rodrguez-Dubra, and E. N. Esteban. 2008. Association of BLV infection profiles with alleles of the BoLA-DRB3.2 gene. Anim. Genet. 39:432-438. https://doi.org/10 $.1111 /$ j.1365-2052.2008.01750.x.

Kaja, R. W., C. Olson, R. F. Rowe, R. H. Stauffacher, L. L. Strozinski, A. R. Hardie, and I. Bause. 1984. Establishment of a bovine leukosis virus-free dairy herd. J. Am. Vet. Med. Assoc. 184:184-185.

Kanno, T., R. Ishihara, S. Hatama, Y. Oue, H. Edamatsu, Y. Konno, S. Tachibana, and K. Murakami. 2014. Effect of freezing treatment on colostrum to prevent the transmission of bovine leukemia virus. J. Vet. Med. Sci. 76:255-257. https://doi.org/10.1292/jvms .13-0253.

Kavanagh, P. J. 1981. Bovine leukosis is now only a sporadic problem in Ireland. Can. Vet. J. 22:396-397.

Kettmann, R., Y. Cleuter, M. Mammerickx, and A. Burny. 1980. Genomic integration of bovine leukaemia provirus: Comparison between persistent lymphocytosis and lymph node tumour form of enzootic bovine leukosis. Arch. Int. Physiol. Biochim. 88:B139.

Khamesipour, F., A. Doosti, A. K. Shahraki, and M. Goodarzi. 2013. Molecular detection of Bovine Leukemia Virus (BLV) in the frozen semen samples of bulls used for artificial insemination in Iran. Res. Opin. Anim. Vet. Sci. 3:412-416.

Kobayashi, S., A. Hidano, T. Tsutsui, T. Yamamoto, Y. Hayama, T. Nishida, N. Muroga, M. Konishi, K. Kameyama, and K. Murakami. 2014. Analysis of risk factors associated with bovine leukemia virus seropositivity within dairy and beef breeding farms in Japan: A nationwide survey. Res. Vet. Sci. 96:47-53. https://doi.org/10 .1016/j.rvsc.2013.11.014.

Kobayashi, S., T. Tsutsui, T. Yamamoto, Y. Hayama, K. Kameyama, M. Konishi, and K. Murakami. 2010. Risk factors associated with within-herd transmission of bovine leukemia virus on dairy farms in Japan. BMC Vet. Res. 6:1-6. https://doi.org/10.1186/1746 $-6148-6-1$.

Kobayashi, S., T. Tsutsui, T. Yamamoto, Y. Hayama, N. Muroga, M. Konishi, K. Kameyama, and K. Murakami. 2015. The role of neighboring infected cattle in bovine leukemia virus transmission risk. J. Vet. Med. Sci. 77:861-863. https://doi.org/10.1292/jvms .15-0007.

Kobayashi, T., Y. Inagaki, N. Ohnuki, R. Sato, S. Murakami, and K. Imakawa. 2019. Increasing Bovine leukemia virus (BLV) proviral load is a risk factor for progression of Enzootic bovine leucosis: A prospective study in Japan. Prev. Vet. Med. 178:104680. https:// doi.org/10.1016/j.prevetmed.2019.04.009.

Kohara, J., S. Konnai, and M. Onuma. 2006. Experimental transmission of Bovine leukemia virus in cattle via rectal palpation. Jpn. J. Vet. Res. 54:25-30.

Kohara, J., M. Takeuchi, Y. Hirano, Y. Sakurai, and T. Takahashi. 2018. Vector control efficacy of fly nets on preventing bovine leukemia virus transmission. J. Vet. Med. Sci. 80:1524-1527. https:// doi.org/10.1292/jvms.18-0199.

Kuczewski, A., H. Hogeveen, K. Orsel, R. Wolf, J. Thompson, E. Spackman, and F. van der Meer. 2019. Economic evaluation of 4 bovine leukemia virus control strategies for Alberta dairy farms. J. Dairy Sci. 102:2578-2592. https://doi.org/10.3168/jds.2018-15341.

LaDronka, R. M., S. Ainsworth, M. J. Wilkins, B. Norby, T. M. Byrem, and P. C. Bartlett. 2018. Prevalence of bovine leukemia virus antibodies in US dairy cattle. Vet. Med. Int. 2018:5831278. https: //doi.org/10.1155/2018/5831278.

Lairmore, M. D. 2014. Animal models of bovine leukemia virus and human T-lymphotrophic virus type-1: Insights in transmission and pathogenesis. Annu. Rev. Anim. Biosci. 2:189-208. https://doi .org/10.1146/annurev-animal-022513-114117.

Leach, K. A., H. R. Whay, C. M. Maggs, Z. E. Barker, E. S. Paul, A. K. Bell, and D. C. Main. 2010. Working towards a reduction in cattle lameness: 1 . Understanding barriers to lameness control on dairy farms. Res. Vet. Sci. 89:311-317. https://doi.org/10.1016/j .rvsc.2010.02.014.

Lojkić, I., D. Balić, N. Rudan, M. Kovačić, Z. Čač, M. Periškić, T. Bedeković, B. Roić, and I. C. Grozdanić. 2013. Eradication of bovine leukosis virus on a dairy farm through improved virus detection. Vet. Arh. 83:581-591.

Mammerickx, M. 1984. Eradication of enzootic bovine leukemia virus infection; Conditions for success and reasons of failure. Pages 443-456 in Fifth International Symposium on Bovine Leukosis, Tübingen, Germany. O. C. Straub, ed. Commission of the European Communities, Luxembourg, Switzerland.

Meas, S., T. Usui, K. Ohashi, C. Sugimoto, and M. Onuma. 2002. Vertical transmission of bovine leukemia virus and bovine immunodeficiency virus in dairy cattle herds. Vet. Microbiol. 84:275-282. https://doi.org/10.1016/s0378-1135(01)00458-8.

Mekata, H., S. Sekiguchi, S. Konnai, Y. Kirino, K. Honkawa, N. Nonaka, Y. Horii, and J. Norimine. 2015. Evaluation of the natural perinatal transmission of bovine leukaemia virus. Vet. Rec. 176:254. https://doi.org/ 10.1136/vr.102464.

Mekata, H., M. Yamamoto, T. Hayashi, Y. Kirino, S. Sekiguchi, S. Konnai, Y. Horii, and J. Norimine. 2018. Cattle with a low bovine leukemia virus proviral load are rarely an infectious source. Jpn. J. Vet. Res. 66:157-163. https://doi.org/10.14943/jjvr.66.3.157.

Merlini, R., G. Gutiérrez, I. Alvarez, J. P. Jaworski, H. Carignano, M. Poli, L. Willems, and K. Trono. 2016. Bovine leukemia virus becomes established in dairy herds before the first lactation. Arch. Virol. 161:3215-3217. https://doi.org/10.1007/s00705-016-2973-x.

Mészáros, J., T. Antal, A. T. Polner, L. Sümeghy, I. Szabó, and G. Vajda. 1994. Eradication of bovine leukosis from a heavily infected herd by the use of own offspring. Acta Vet. Hung. 42:421-432.

Molloy, J. B., C. K. Dimmock, F. W. Eaves, A. G. Bruyeres, J. A. Cowley, and W. H. Ward. 1994. Control of bovine leukaemia virus transmission by selective culling of infected cattle on the basis of viral antigen expression in lymphocyte cultures. Vet. Microbiol. 39:323-333. https://doi.org/10.1016/0378-1135(94)90168-6.

Morris, S. D., N. R. Bryson, D. T. de Waal, O. Matthee, E. R. du Preez, M. van Vuuren, and E. S. Kadish. 1996. The possible role of two common three-host ticks, Rhipicephalus appendiculatus and Amblyomma hebraeum, in the transmission of bovine leukosis virus. J. S. Afr. Vet. Assoc. 67:148-150.

Nagy, D. W., J. W. Tyler, and S. B. Kleiboeker. 2007. Decreased periparturient transmission of bovine leukosis virus in colostrumfed calves. J. Vet. Intern. Med. 21:1104-1107. https://doi.org/10 $.1111 /$ j.1939-1676.2007.tb03071.x.

Nakada, S., J. Kohara, and K. Makita. 2018. Estimation of circulating bovine leukemia virus levels using conventional blood cell counts. J. Dairy Sci. 101:11229-11236. https://doi.org/10.3168/jds.2018 $-14609$.

Nekouei, O., J. VanLeeuwen, J. Sanchez, D. Kelton, A. Tiwari, and G. Keefe. 2015. Herd-level risk factors for infection with bovine leukemia virus in Canadian dairy herds. Prev. Vet. Med. 119:105-113. https://doi.org/10.1016/j.prevetmed.2015.02.025.

Nishiike, M., M. Haoka, T. Doi, T. Kohda, and M. Mukamoto. 2016. Development of a preliminary diagnostic measure for bovine leukosis in dairy cows using peripheral white blood cell and lymphocyte counts. J. Vet. Med. Sci. 78:1145-1151. https://doi.org/10.1292/ jvms.16-0022.

Norby, B., P. C. Bartlett, T. M. Byrem, and R. J. Erskine. 2016. Effect of infection with bovine leukemia virus on milk production in Michigan dairy cows. J. Dairy Sci. 99:2043-2052. https://doi.org/ 10.3168/jds.2015-10089.

Nuotio, L., H. Rusanen, L. Sihvonen, and E. Neuvonen. 2003. Eradication of enzootic bovine leukosis from Finland. Prev. Vet. Med. 59:43-49. https://doi.org/10.1016/S0167-5877(03)00057-6.

Ohno, A., S. Takeshima, Y. Matsumoto, and Y. Aida. 2015. Risk factors associated with increased bovine leukemia virus proviral load in infected cattle in Japan from 2012 to 2014. Virus Res. 210:283290. https://doi.org/10.1016/j.virusres.2015.08.020.

OIE (World Organisation for Animal Health). 2018. Enzootic bovine leukosis. Chapter 2.4.11 in Manual of Diagnostic Tests and Vac- 
cines for Terrestrial Animals. Accessed Sep. 1, 2020. https://www .oie.int/fileadmin/Home/eng/Health_standards/tahm/2.04.10 EBL.pdf.

Ooshiro, M., S. Konnai, Y. Katagiri, M. Afuso, N. Arakaki, O. Tsuha, S. Murata, and K. Ohashi. 2013. Horizontal transmission of bovine leukaemia virus from lymphocytotic cattle, and beneficial effects of insect vector control. Vet. Rec. 173:527. https://doi.org/10.1136/ vr.101833.

Panei, C. J., A. E. Larsen, N. A. Fuentealba, G. E. Metz, M. G. Echeverria, C. M. Galosi, and A. R. Valera. 2019. Study of horn flies as vectors of bovine leukemia virus. Open Vet. J. 9:33-37. https:/ /doi.org/10.4314/ovj.v9i1.6.

Pannwitz, S., O. Schulz, and K. Kirchner. 1987. Experiences in restoring cattle stock free of enzootic bovine leukosis in the Neubrandenburg district. Arch. Exp. Veterinarmed. 41:748-751.

Queensland Government Department of Agriculture and Fisheries. 2016. EBL dairy freedom program. Accessed Aug. 27, 2019. https://www.daf.qld.gov.au/business-priorities/biosecurity/ animal-biosecurity-welfare/animal-health-pests-diseases/a-z-list -of-significant-animal-pests-and-diseases/enzootic-bovine-leucosis -ebl/ebl-dairy-freedom-program.

Ramírez Vásquez, N. F., D. Villar Argaiz, J. A. Fernández Silva, J. Londoño Pino, J. J. Chaparro Gutiérrez, and M. E. Olivera Ángel. 2016. Seroprevalence and risk factors of several bovine viral diseases in dairy farms of San Pedro de los Milagros, Antioquia, Colombia. CES Med. Vet. Zootec. 11:15-25. https://doi.org/10 .21615/cesmvz.11.1.2.

Roberts, D. H., and S. Bushnell. 1982. Herd eradication of enzootic bovine leukosis. Vet. Rec. 111:487. https://doi.org/10.1136/vr.111 .21 .487

Rodríguez, S. M., A. Florins, N. Gillet, A. De Brogniez, M. T. Sánchez-Alcaraz, M. Boxus, F. Boulanger, G. Gutiérrez, K. Trono, I. Alvarez, L. Vagnoni, and L. Willems. 2011. Preventive and therapeutic strategies for bovine leukemia virus: Lessons for HTLV. Viruses 3:1210-1248. https://doi.org/10.3390/v3071210.

Rola-Euszczak, M., C. Finnegan, M. Olech, B. Choudhury, and J. Kuzmak. 2013. Development of an improved real time PCR for the detection of bovine leukaemia provirus nucleic acid and its use in the clarification of inconclusive serological test results. J. Virol. Methods 189:258-264. https://doi.org/10.1016/j.jviromet.2013.02 .014 .

Ruggiero, V. J. 2019. Field studies on the control of bovine leukemia virus in dairy cows. PhD Diss. Michigan State University, Ann Arbor.

Ruggiero, V. J., and P. C. Bartlett. 2019. Control of bovine leukemia virus in three US dairy herds by culling ELISA-positive cows. Vet. Med. Int. 2019:3202184. https://doi.org/10.1155/2019/3202184.

Ruggiero, V. J., B. Norby, O. J. Benitez, H. Hutchinson, K. R. B. Sporer, C. Droscha, C. L. Swenson, and P. C. Bartlett. 2019. Controlling bovine leukemia virus in dairy herds by identifying and removing cows with the highest proviral load and lymphocyte counts. J. Dairy Sci. 102:9165-9175. https://doi.org/10.3168/jds 2018-16186.

Ruiz, V., N. G. Porta, M. Lomonaco, K. Trono, and I. Alvarez. 2018. Bovine leukemia virus infection in neonatal calves. Risk factors and control measures. Front. Vet. Sci. 5:267. https://doi.org/10 .3389 /fvets.2018.00267.

Ruppanner, R., D. E. Behymer, S. Paul, J. M. Miller, and G. H. Theilen. 1983. A strategy for control of bovine leukemia virus infection: Test and corrective management. Can. Vet. J. 24:192-195.

Sajiki, Y., S. Konnai, A. Nishimori, T. Okagawa, N. Maekawa, S. Goto, M. Nagano, J. Kohara, N. Kitano, T. Takahashi, M. Tajima, H. Mekata, Y. Horii, S. Murata, and K. Ohashi. 2017. Intrauterine infection with bovine leukemia virus in pregnant dam with high viral load. J. Vet. Med. Sci. 79:2036-2039. https://doi.org/10.1292/ jvms.17-0391.

Sargeant, J. M., D. F. Kelton, S. W. Martin, and E. D. Mann. 1997. Associations between farm management practices, productivity, and bovine leukemia virus infection in Ontario dairy herds. Prev. Vet. Med. 31:211-221. https://doi.org/10.1016/S0167 $-5877(96) 01140-3$

Schwartz, I., and D. Levy. 1994. Pathobiology of bovine leukemia virus. Vet. Res. 25:521-536.

Scott, H. M., O. Sorensen, J. T. Wu, E. Y. Chow, K. Manninen, and J. A. VanLeeuwen. 2006. Seroprevalence of Mycobacterium avium subspecies paratuberculosis, Neospora caninum, Bovine leukemia virus, and Bovine viral diarrhea virus infection among dairy cattle and herds in Alberta and agroecological risk factors associated with seropositivity. Can. Vet. J. 47:981-991.

Şevik, M., O. Avc1, and Ö. B. Ince. 2015. An 8-year longitudinal seroepidemiological study of bovine leukaemia virus (BLV) infection in dairy cattle in Turkey and analysis of risk factors associated with BLV seropositivity. Trop. Anim. Health Prod. 47:715-720. https:/ /doi.org/10.1007/s11250-015-0783-x.

Sharifzadeh, A., A. Doosti, and P. G. Dehkordi. 2011. Molecular detection of bovine leukemia virus (BLV) in the semen samples of bulls. World J. Zoology 6:285-290.

Shettigara, P. T., B. S. Samagh, and E. M. Lobinowich. 1986. Eradication of bovine leukemia virus infection in commercial dairy herds using the agar gel immunodiffusion test. Can. J. Vet. Res. 50:221226.

Shettigara, P. T., B. S. Samagh, and E. M. Lobinowich. 1989. Control of bovine leukemia virus infection in dairy herds by agar gel immunodiffusion test and segregation of reactors. Can. J. Vet. Res. $53: 108-110$

Sorge, U., D. Kelton, K. Lissemore, A. Godkin, S. Hendrick, and S. Wells. 2010. Attitudes of Canadian dairy farmers toward a voluntary Johne's disease control program. J. Dairy Sci. 93:1491-1499. https://doi.org/10.3168/jds.2009-2447.

Sprecher, D. J., K. D. Pelzer, and P. Lessard. 1991. Possible effect of altered management practices on seroprevalence of bovine leukemia virus in heifers of a dairy herd with history of high prevalence of infection. J. Am. Vet. Med. Assoc. 199:584-588.

Suh, G. H., J. Lee, C. Lee, T. Hur, D. Son, B. Ahn, N. Kim, and C. Lee. 2005. Establishment of a bovine leukaemia virus-free dairy herd in Korea. J. Vet. Sci. 6:227-230. https://doi.org/10.4142/jvs .2005.6.3.227.

Sun, W., W. Lv, W. Cong, Q. Meng, C. Wang, X. Shan, and A. Qian. 2015. Mycobacterium avium subspecies paratuberculosis and bovine leukemia virus seroprevalence and associated risk factors in commercial dairy and beef cattle in northern and northeastern China. Biomed Res. Int. 2015:315173. https://doi.org/10.1155/ $2015 / 315173$.

Voges, H. 2012. New Zealand dairy enzootic bovine leukosis (EBL) control scheme. Surveillance 39:41.

Wang, C. T., and M. Onuma. 1992. Attempt to eradicate bovine leukemia virus-infected cattle from herds. Jpn. J. Vet. Res. 40:105-111.

Yoshikawa, H., T. Yoshikawa, T. Oyamada, T. Sasaki, H. Koyama, and S. Tsubaki. 1992. Establishment and maintenance of bovine leukosis virus-free farm. Kitasato Arch. Exp. Med. 65:137-141.

Yuan, Y., Y. Kitamura-Muramatsu, S. Saito, H. Ishizaki, M. Nakano, S. Haga, K. Matoba, A. Ohno, H. Murakami, S. N. Takeshima, and Y. Aida. 2015. Detection of the BLV provirus from nasal secretion and saliva samples using BLV-CoCoMo-qPCR-2: Comparison with blood samples from the same cattle. Virus Res. 210:248-254. https: //doi.org/10.1016/j.virusres.2015.08.013. 